\title{
A genealogical inquiry into early Islamism: the discourse of Hasan al-Banna
}

\author{
ANDREA MURA
}

Department of Politics and International Relations, University of Aberdeen, Aberdeen $A B 243 Y Q, U K$

\begin{abstract}
This article inquires into the ideological vision of Hasan al-Banna (1906-1949), one of the most influential figures of Islamist thought. By assuming a discourse theory perspective, I argue that al-Banna's Islamist discourse was genealogically caught between a traditional pan-Islamic vocation and modern ways of articulating political discourse, such as nationalism and Arab nationalism. Following the traumatic encounter between tradition and modernity that colonialism enacted, al-Banna increasingly integrated and valourized modern national 'signifiers', downplaying early universalistic ethos. This denoted a growing reliance on the language of modernity over the language of tradition, though such reliance was instrumental to al-Banna's anti-imperialist political project, entailing the very preservation of tradition as a moderator principle in the appropriation of modernity.
\end{abstract}

In recent years, several scholars in the field of political sociology and international relations have centred upon the relation between globalization and Islamism, highlighting the manner in which a number of Islamist organizations have increasingly adapted to a decentred context, privileging a transnational view. ${ }^{1}$

In contrast, others have pointed to a sort of 'nationalization' of the Islamist project. Prominent scholars, such as Gilles Kepel and Olivier Roy, have seen the Islamist adoption of a national agenda as the result of the progressive erosion of the original ideological and anti-secularist stance assumed by Islamist movements. ${ }^{2}$ Naturally, this variety of interpretations testifies to the ideological complexity of Islamism, evidencing the multiplicity of agendas that Islamist movements foster within the Islamist 'galaxy'.

This article examines the 'nationalized' tendency alone, focusing on what could be described as a sort of foundational discourse of this trajectory: the discourse of Hasan al-Banna (1906-1949). I will show that Islamism reflected modern and national characteristics since its very inception. Nationalization was not the 
outcome of years of failure, but the result of the inner discursive tendencies that had been developed already by al-Banna, the founder of the first Islamist organization of modern history, the Society of the Muslim Brothers (hereafter, the Brotherhood or the Society). By exploring al-Banna's vision, it will be possible to grasp some of the most relevant ideological features that nowadays still inform what has been called a 'mainstream' tendency of Islamism. ${ }^{3}$

In the first section, I will introduce the reader to the historical development of the Brotherhood, examining two discourses informing al-Banna's genealogical context, i.e. the discourse of Islamic universalism and the discourse of the nation. The second section will then provide a focused presentation and analysis of al-Banna's thought. A textual examination of al-Banna's pamphlets will be pursued accompanied by a theoretical assessment of his ideas on community and space. This will permit me to uncover the discursive strategies that al-Banna devised in his attempt to elaborate his anti-imperialist project.

\section{A genealogical frame}

The historical context framing Hasan al-Banna's discursive trajectory in the first half of the 20th century was one marked by harsh cultural and political tensions, very much the result of the increasing penetration of colonial powers into Muslim settings. Among the dramatic events preceding al-Banna's foundation of the Brotherhood in 1928, the abolition of the caliphate by the westernized Young Turks in 1924 had certainly represented a traumatic turning point, contributing to the process of social and discursive desedimentation already begun under the pressure of colonialism. In Egypt, the persistent and assertive presence of the British exacerbated political tensions, in a social context already divided between 'modernists', who advocated a stronger secularism in Egypt (emblematized by the secularist position of intellectuals such as Taha Husain and Ali Abd al-Razik), Muslim orthodox, who assumed a conservative stance and opposed most political and cultural changes (epitomized by Al-Azhar University) and religious reformists who advocated an assertive defence of Islam from secularism, while, at the same time, demanding ijthad, which is some form of interpretation and reform of religious doctrines (for instance, the position of Mummad Rashid Rida). ${ }^{4}$ But divisions occurred also between pro-western lay nationalists, who celebrated the Pharaonic and 'ethnic' origin of the nation, and those nationalists who instead wanted to preserve also the Islamic quality of Egypt. ${ }^{5}$

After the declaration of a British protectorate over Egypt during World War I, the British recognition of Egyptian 'independence' in 1922 remained a formal one, with the right of Britain to retain control over Egyptian foreign and internal policy in the name of British interests in the Suez Canal and Sudan. ${ }^{6}$ Egypt remained a de facto colony dominated by the manoeuvrings of the Egyptian King and the British who aimed at discrediting political opposition. ${ }^{7}$ The exclusion from power and the obstacles faced by the popular nationalist party Wafd, despite its persistent political and electoral success, slowly succeeded in undermining the image of 
Egyptian 'liberal nationalism' epitomized by the Wafd. At the same time, however, this contributed to a discrediting of liberal politics in general. ${ }^{8}$

In discursive terms, colonial interference might be said to have produced the overlapping of two different languages in the delineation of political projects, and the constructions of notions of space and subjectivity. I am referring to the encounter between the language of 'tradition' and the language of 'modernity'. I should stress that I do not define here tradition and modernity as definite historical epochs or sociological conditions characterized by some sort of temporal sequence. I am rather interested is using these categories as convenient indicators or indexes in the organization of discourses. I define tradition and modernity as competing and fictional horizons of the linguistic space, imaginative containers or vocabularies delineating a plurality of discourses and embodying for that very reason the range of signifiers that each discourse articulates.

When considering the Islamic tradition, for instance, I agree with Samira Haj that the term 'tradition' should be thought of as a 'framework of inquiry rather than a set of unchanging doctrines or culturally specific mandates. ${ }^{9}$ Haj points here to Talal Asad's conceptualization of tradition as the ensemble of those 'discourses that seek to instruct practitioners regarding the correct form and purpose of a given practice that, precisely because it is established, has a history. ${ }^{10}$ Within this framework, I characterize the Islamic tradition, turāth, in terms of a vocabulary embodying a plurality of discourses on shari'ah (Islamic law), fiqh (Islamic jurisprudence), jihad (spiritual and military effort on behalf of Islam), Sufism (mystical tradition), dar al-Islam (Islamic territoriality), waqf (religious endowment), caliphate, Islamic universalism, and others.

Similarly, I define 'modernity' as a discursive scenario condensing a plurality of discourses around three main poles: a structural connotation (modernist socioeconomic discourses on 'industrialization', 'institutional differentiation', 'scientific rationality', the belief in 'progress', etc.); an ideological connotation (modernity as a political project articulating a set of discourses based on a binary logic and resulting in the constitution of modern sovereignty and modern subjectivity); and a moral connotation (discourses about the moral disquiets of modernity, e.g. individualism, atomism, alienation, relativism, materialism, etc.).

Naturally, the inclusion of discourses within the discursive boundaries of 'tradition' and 'modernity' very much reflects the way people themselves tend to qualify a certain narrative, defining it, for instance, either as 'modern' or 'traditional' (something that is evident in the harsh cultural debates between selfdefining 'modernists' and 'traditionalists' in Egypt in the 1920s). ${ }^{11}$ Moreover, the allocation of discourses within these broad discursive scenarios is also explained on the ground of the linguistic proximity that they express in converging in that vocabulary, a proximity reflecting a certain discursive resonance in the way the social is organized and accounted for. This proximity allows both tradition and modernity to figure as a 'history of argument and debate over certain fundamental doctrines in shared languages and styles of discourse. ${ }^{12}$ This means that although a certain degree of fluidity is always present in delineating the discursive boundaries of tradition and modernity, their symbolic function is sustained 
precisely by their capacity to 'appear' as fixed and stable totalities, as selfcontained historical narratives. It is through this imaginary capacity that the 'history' of definite discursive practices is established, allowing tradition and modernity to stand as sort of symbolic reservoirs.

Naturally, the imaginary and contingent origin of these reservoirs becomes particularly evident when a traumatic process of social disintegration occurs (e.g. the encounter with colonialism). It is here that the naturalization of discursive practices is contested, social relations unsettled, the unity of certain fields of discursivity disarticulated and meanings de-fixed. ${ }^{13}$ In considering the ultimate encounter that colonialism promoted between modernity and tradition, this article will focus on two discourses, playing a central role in the construction of space and community at that time: the discourse of Islamic universalism (i.e. pan-Islamism) and the discourse of the nation (both in its European and pan-Arab variant). Again, the 'traditional' character of universalism does not deny the ever-changing nature of that discourse, its intellectual transformations. Rather, it simply reflects the perception of universalism as 'belonging' to a specific body of knowledge, to a 'history' or 'language' different from modernity, that is, from that language that 'modernists' celebrated at that time when disseminating discourses on the nation-state (we will see, for instance, that al-Banna himself associated the discourse of the nation with modernity while ascribing a universalistic conception of the world to a 'perceived' Islamic legacy).

\section{The discourse of Islamic universalism}

According to the English scholar Dwight E. Lee, two distinct visions could be identified with the expression 'Islamic universalism'. On the one hand, there was the classic 'tradition' of Muslim unity, aimed at establishing Islamic society on a global scale. Such a discourse was said to promote the 'realization of the Islamic ideal, the unity of the world in Islam, the central direction under a leader (Imam) of the world community. ${ }^{14}$ On the other hand, 'Islamic universalism', and its terminological equivalent 'pan-Islamism', came to indicate a political movement in the 19th century that was promoted by Sultan Abdul Hamid II, emperor of the Ottomans, and inspired by the writings of Persian philosopher and Islamic reformer Jamal ad-Din al-Afghani (1838-1897). This movement called for the unification of all Muslims in order to resist the growing political and military influence of emerging colonial powers from Europe, re-articulating the tradition of Islamic unity, and revitalising its symbolic appeal for anti-imperialist purposes. ${ }^{15}$

Despite the tendency to consider pan-Islamism as a movement epitomizing the intellectual position of al-Afghani and other reformists in the pre-colonial and colonial era, this section focuses on pan-Islamism as the traditional discourse of 'Islamic universalism', a discourse that contributed to connote tradition as a symbolic reservoir, and also inspired al-Afghani's vision. It is not possible here to account for all the different doctrines and intellectual positions characterizing the discourse of Islamic universalism throughout the centuries, from classical views in Islamic thought (e.g. Abu al-Hasan al-Mawardi, Muhammad Shaybani, 
Ibn Taymiyyah, etc.) to more recent elaborations among Islamist theorists (e.g. Sayyid Qutb, Ali Shari'ati, etc.). An examination of this discursive complexity lies outside the limits and the scope of this article. The attempt will be rather to enucleate key historical features in the complex development of this discourse, delineating the general model of spatial representation and subjectivity formation that a universalistic framework enacts.

In broad terms, two main signifiers substantiated the discursive structure of Islamic universalism sustaining its central ideal of Islamic unity: dar al-Islam (the 'domain of Islam', also referred to as 'abode of belief') and the ummah (Muslim community). On the one side, dar al-Islam incarnated the Islamic conception of territoriality. Manoucher Parvin and Maurie Sommer tracked the line of theoretical and historical development of what they saw as the 'dynamic, accommodating processual notion of dar al-Islam. ${ }^{16}$ The dar al-Islam was theologically defined as a sort of immediate presence, expressing the domain of faith and the full realization of humanity. Against this original domain, however, early jurists of Islam had to acknowledge the existence of lands ruled by non-Muslims, which denoted the dar al-harb (the abode of war or chaos). In this scenario, dar al-Islam remained for long time inclusive and accommodating, regulated by difference and integration, with an outside (dar al-harb) treated as a temporary external space to be subsumed, sooner or later, under the banner of the Islamic universalism. As Middle East scholar Majid Khadduri observes, in fact, 'the dar al-Islam, in theory, was in a state of war with the dar al-harb, because the ultimate objective of Islam was the whole world'. ${ }^{17}$ In mentioning Kitab al-Mabsut (The Book of Expatiation), a key legal text by Central Asian Hanafite jurist al-Sarakhsi, Khadduri notes that 'if the dar al-harb were reduced by Islam, the public order of Pax Islamica would supersede all others, and non-Muslim communities would either become part of the Islamic community or submit to its sovereignty as tolerated religious community or as autonomous entity possessing treaty relations with it. ${ }^{18}$ This meant that not real and permanent outside could be thought of in the all-encompassing space of Islamic universality, for non-Muslim lands were destined to be either integrated as internal differences (in the form of tolerated communities) or Islamized and henceforth assumed as internal Muslim constituencies.

In the early times of Islamic expansionism, this spatial model was revealed with particular clarity, for Islamic territoriality, dar al-Islam, was (ideally) able to absorb its non-Muslim outside (dar al-harb), realizing a kind of fully human/fully Muslim 'universality' which transcended closed, exclusive communities based on soil, blood, culture, etc. But while dar al-Islam upset and broadened previous groupings, it required commitment to a set of substantive rules and norms: in other words, a commitment to a shared ethical form of life (i.e. shari'ah as an all-inclusive and integral conception of life).

Naturally, positions towards the antagonistic nature of Islamic universalism varied according to eschatological views and legal conceptualizations. Shafi'i jurists, for instance, tempered the polarization between dar al-Islam and dar al-harb by adopting a new legal category, dar al-'ahd, (basically, a non-Muslim 
land not at war against Islam), which functioned as a moderator principle, allowing treaty relations with non-Muslims. ${ }^{19}$ This legal category became more and more important as the dynamic, yet expansionist movements of the early Islamic age got gradually reduced in the face of the permanence and increasing visibility of non-Muslim lands, which finally clashed with the universalistic ideal of Islam that the initial expansion had sustained. A principle of pragmatism on behalf of the Islamic interest, maslaha, led then the Shafi' is legal school to assume a more moderate approach towards Islamic universality, even though the ideal of Muslim unity, as epitomized by the caliphate, kept expressing its symbolic appeal throughout the centuries. ${ }^{20}$

In this complex and universalistic space, mention should be made of the dawlah, the political entity that, following the increasing political fragmentation of Islam after the decline of the Abbasids, began to appear as a sort of administrative unit of dar al-Islam. Although the dawlah is often associated with the concept of the nation-state, the two constructs reveal significant conceptual differences. Tamim Barghuthi notes that the ruler of the dawlah was not only accountable internally towards its domestic constituencies (the 'subjects' of the dawlah) as it was the case with the nation-state. ${ }^{21}$ An outward accountability was also established externally with the caliph, which incarnated the whole Muslim community on a global scale. Thus, the dawlah figured as a substantially open entity, expressing a complex sense of loyalty that blurred the rigid distinction between domestic and foreign entities at the heart of the national model.

As for the Muslim community (the Muslim ummah), this was also marked by a universalistic notion of integration. This inclusive stance was best demonstrated by the variety of ethnic groups that, at different times, took pre-eminence over the ummah, assuming the historical role of its diffusion and expansion (i.e. in the dominion of Arabs, Mongols, Turks, etc.). As with the case of dar al-Islam, a religious and 'normative' character of the ummah informed such a universality. Talal Asad, for instance, claims that members of every community imagined the ummah to be grounded in a specific character and related to each other on the basis of that feature. 'The crucial point therefore is not that it is imagined but that what is imagined predicates distinctive modes of being and acting. ${ }^{22}$ This means that while functioning as a universal abstract principle, the shared ethical form of life that the ummah expressed, in conjunction with its spatial transposal in the dar al-Islam, was grounded in a 'multiplicity' of representations, each one defining a 'particular' (cultural, historical), 'mode of being' of that universality. Here, normativity functions as the internal logic of universal space. It allows individuals to emerge as 'self-governing, but not autonomous', as if individuality within the ummah results from the very adoption of a common Islamic ethos rather than preceding it as a pre-determined origin. ${ }^{23}$ This seems to resonate with classical conceptualizations about the nature of multiplicities. In his recent account of the multitude, for instance, Virno observes that although a multitude values individuality, the latter should be thought of as 'the final product of a process of individuation which stems from the universal, the generic, the pre-individual. ${ }^{24}$ I will now elucidate the way such a model differs from its national counterpart. 


\section{The discourse of the nation}

The symbolic function of modernity was also central, alongside tradition, in the discursive arena of pre-revolutionary Egypt. A crucial role was played here by the discourse of the nation that the main actors of Egyptian politics, i.e. the British, the King, the ruling elite and the Wafd highly celebrated, testifying to the increasing hegemonic power of nationalism.

In the European context, the nation-state had come forward as a historical development of patrimonial and absolutist models of power. Central to the point was the constitutional transformation of the modern state, which entailed the evolution of modern sovereignty in search of a new source of legitimation. In modern juridical doctrines, sovereignty had been conceptualized as the supreme 'power' (summa potestas) giving 'force' and 'authority' to a political order by way of its 'absolute and perpetual' (Bodin), 'exclusive and indivisible' (Hobbes) essence. ${ }^{25}$ The supreme power of a political order was thought of, therefore, as the original, unrestricted and unique source of legitimacy of state control, which does not recognize any superior principle of power outside itself. In this theoretical frame, major shifts, however, regarded the locus of authority, that is, the subject incarnating this supreme power of political order. In the doctrinal evolution of theories of sovereignty, the locus of power ended up coinciding with the nation-state, incarnating the people of the state and its territory. 'Sovereignty', 'people' and 'territory' constitute three main signifiers of the discourse of the nation.

Within the borders of such a discourse, national identity has been described as a creative energy, a product of the 'collective imagination' marking the shift from a passive to an active role of population (with the final transition from the feudal 'subject' to the modern 'citizen'). ${ }^{26}$ A central step was the identification by local populations with the signifying image of the people. In connoting this key signifier of the national discourse, dualism provided an essential hierarchical principle. As for other types of modern subjectivity formations, this entailed overemphasizing similarities in blood, language and history and, at the same time, subsuming differences within the unitary spiritual and henceforth transcendental dimension of the people. ${ }^{27}$ Standardization of both national languages and historical narratives, the emphasis on the racial character of the people, the juridical conceptualization of national territory, with citizenship legally anchored to the two principles of jus soli ('right of the territory', citizenship based on actual birth in the territory of the nation-state) and jus sanguinis ('right of blood', citizenship recognized on the basis of line of descent)-(these were all features marking, with different degrees of intensity, the construction of national identities.

So obtained, national identity was then taken to constitute an undividable sacred Self, which was thought of in radical antagonism with its outside, the realm of exclusion, what remained external to it (that is, competing nations). We saw earlier that in the universalistic space, the inside was conceptualized as a necessary and immediate presence in the face of the accidental and temporary manifestation of the outside. Moreover, the relation between these two domains (inside and outside) was an inclusive one. The peculiarity of the national model, instead, was 
that the two domains were thought of on the ground of an 'absolute negation': alterity was used in the very production of Self through a reversal of its 'essences'. It was the antagonistic relation with 'other/outside' that was necessary for the very delineation of the 'self/inside'. The world of modern sovereignty turned out to be a Manichean world, marked by an infinite series of dichotomies defining the Other as uncivilized, emotional, despotic, etc., and then depicting the Self as its very opposite: civilized, rational, democratic, etc. Although some authors have seen in this a 'pathological' articulation of identity, the deployment of this dualistic logic in the construction of nation-states has been amply acknowledged. ${ }^{28}$

Moreover, alongside this new re-formulation of selfhood and community, a new cognition of space, in the form of the national territory, was also devised, which substantially adopted the same binary mechanism of exclusion. The national territory constitutes another central signifier of the discourse of the nation, one that marks the very origin of its etymological root (from Latin nasci, the term nation coveys the idea 'to be born' into a certain land). The consolidation of the modern state, especially in the form of the nation-state, in fact, required first and foremost the creation of clear-cut frontiers. This entailed the absorption of those portions of landscape that previously separated the land of different lords, and that were not recognized by any state. An increasing process of rationalization of land and population under modern notions of sovereignty was therefore promoted on the ground of a dualistic logic. ${ }^{29}$ It is with the modern absolutist state and the nation-state in particular that territory came to be fully symbolized, with frontiers across European states being inherently organized on the basis of territorial contact. ${ }^{30}$ Naturally, the rationalization of population and land was not the result of some kind of structural telos. It required indeed the adoption of definite symbolic criteria organizing the discursive and administrative 'formation' of the nation-state. As Mark Purcell observed, 'in the process of imagining the nation, actors also imagine the territory that goes with that nation $[\ldots]$ National territory is imagined to have certain characteristics, a certain landscape, certain boundaries, certain focal points. ${ }^{31}$ Like the binary construction of the people, the national concept of territory entailed a necessary and exclusionary model of imagining space, as the end of my territory necessarily coincides with the beginning of yours. The dualistic character entailed by this model rests not so much in the existence and necessary relation with an outside, but in the very nature of such a relation. As for the notion of the people, the territorial outside is not treated, in fact, in terms of mere difference; rather, it is assumed as a necessary absolute negation, where exclusion needs to be maintained for the very basic functioning of the inside as a whole, as an Us.

By reflecting the form, par excellence, of identification based on the 'us' and 'them' paradigms, the nation-state, with its binary construction of space and subjectivity, was able to exert a significant control within its borders while competing with other nation-states for political and economic dominion outside its boundaries. ${ }^{32}$ Relating identity to territory, the doctrine of the nation-state exerted a massive capacity of mobilization well beyond Europe. Although differences have characterized the articulation of the national discourse in specific settings 
(for instance, signifiers such as 'religion' and 'race' have played different roles in connoting the signifier 'people' in distinct environments), the dualistic structure of this model remained substantially intact in colonial contexts. As Susanne Reimer observes, "the limited sovereignty and territory of the colony was already imagined for the colonized by the colonizers. ${ }^{33}$

\section{The foundation of the Brotherhood}

It is in this genealogical context that the Egyptian young schoolmaster Hasan al-Banna (1906-1949) founded the Muslim Brotherhood in 1928, a movement articulating a new kind of political discourse, which will henceforth be known as 'Islamism'. The Brotherhood was thought of as an organization aimed at providing welfare services for the population, encouraging and defending morality, and 'Islamizing' society. In the 1950s and 1960s, 'modernist' scholars tended to stress the 'anti-modern' character of this ethical dimension in the Brotherhood's agenda, which was said to reveal a conservative stance. ${ }^{34}$ Unlike the understanding of 'modernity' advanced in these pages, 'modernist' theories interpreted modernity as a sociological condition coinciding with the process of industrialization, an increasing institutional differentiation and specific cultural paradigms (scientific rationality, secularization, the belief in progress). In this scenario, the Brotherhood was not only reduced to the fundamentalist idea of a return to a mythical past, which was said to reflect a dismissal of modernity as such, but also its emphasis on social integration was seen as incompatible with the 'modern' tendency towards social differentiation.

In contrast, other analyses have emphasized the Brotherhood's socio-structural adaptation to modernity. ${ }^{35}$ Branjar Lia, for instance, showed that the combination of social and religious credentials and the deployment of a modern organization and propaganda tools qualified the Muslim Brotherhood as a modern "mass social movement'. ${ }^{36}$ Similar approaches have given greater emphasis to ideological factors. ${ }^{37}$ Some have tended to highlight the intellectual relation between al-Banna and the great reformists of the 19th century, such as Jamal al-Din al-Afghani and Muhammad 'Abduh, evidencing the common attempt to modernize the Islamic tradition. ${ }^{38}$ Others have focused on the political strategy of the Brotherhood, highlighting its early commitment to a modern anti-imperialist politics. ${ }^{39}$ In this context, although the increasingly troubled political context favoured the radicalization of the Brotherhood's political philosophy and tactics_-just like its 'secular' nationalist counterparts-it has been observed that the main focus of the Society remained for a long time on Islamization 'from below' and the infiltration of political and social institutions in Egypt. ${ }^{40}$

It should be noted, however, that the Brotherhood never stopped looking at the entire Islamic world, promoting its Islamic call well beyond Egyptian borders. For instance, Islamic universalism played a crucial role behind the Brotherhood's pro-Palestinian campaign organized during the dramatic riots in Palestine in 1936-1937, and again behind the Brotherhood's military and ideological contribution to the first Arab-Israeli War in 1948, which eventually allowed the 
Society to gain a strong reputation among the Egyptian army and the population. ${ }^{41}$ Political focus, however, rested primarily on the reformation of Egyptian politics, not a universal Muslim community.

This is something most of the above-mentioned studies have acknowledged, emphasizing the Brotherhood's passionate commitment to the cause of national independence. The speculative implications of such a perspective, however, have remained largely unexplained from a political theory standpoint. What did either a national or a universalistic agenda involve in terms of imagining community, identity and territoriality or in the very construction of the other/outside? It is here that the discussion presented earlier concerning the discourse of Islamic universalism and the discourse of the nation assumes its relevance. In the following pages, I address this range of questions, examining al-Banna's intellectual trajectory vis-à-vis the dominant languages of his times, such as modernity and tradition. Going beyond scholarly acknowledgments about al-Banna's geopolitical focus on domestic reality, the objective is to track key discursive shifts in his vision, assessing the potential for contestation of his writings. I will thus be able to evidence al-Banna's elaboration of what could be called a 'territorial' trajectory of Islamism, which denoted, in discursive terms, the attempt to dislocate western monopoly over the discourse of the nation, pursuing a counter-hegemonic articulation and valourization of national signifiers.

\section{Hasan al-Banna's articulatory practice: a discursive inquiry ${ }^{42}$}

The early writings (1928-1930) ${ }^{43}$

Hasan al-Banna began his teachings in the coffee shops of Ismailia, a small town near the Suez Canal where the presence of British soldiers and settlers, besides marking a strong social inequality between Egyptians and Europeans, entailed the direct and visible cultural influence of the West. ${ }^{44}$ In his first article after the foundation of the Brotherhood in 1928, al-Banna explicitly criticizes the spiritual quiescence of official Islam and the Egyptian political establishment in general, together with their inability to counter western secularization and materialism:

What catastrophe has befallen the souls of the reformers and the spirit of the leaders? What has carried away the ardour of the zealots? What calamity has made them prefer this life to the thereafter? What has made them ... consider the way of struggle [sabil al-jihad] too rough and difficult? ${ }^{45}$

From the very beginning, al-Banna focuses his attention on the 'way of struggle (sabil al-jihad)' for an Islamization from below, that is, the assertive endeavour to awaken people's conscience by calling for the sovereignty of God in every section of society. Hence, a place of pleasure such as a coffee shop is transformed into a platform for the Islamic call (da'wa). In one of the early pamphlets written in 1934, To What Do We Invite Humanity? while inviting Muslims to 'rebuild' the community on the basis of Islamic tenets, al-Banna is adamant in considering supreme outcome not as a consequence of a state initiative but as the ultimate 
result of individual spiritual efforts (sabil al-jihad, spiritual effort in the path of God):

Muslims, this is a period of rebuilding: re-build yourselves, and your Umma will as a consequence be rebuilt! ${ }^{46}$

This signals al-Banna's early attempt to assume a moderate and gradualist bottom-up approach to Islamization (from the individual to the society). In this same pamphlet, moreover, the main objectives of the Brotherhood are defined in clear terms:

To establish Allah's sovereignty over the world. To guide all of humanity to the precepts of Islam and its teachings (without which mankind cannot attain happiness). ${ }^{47}$

A few caveats are needed, however, in consideration of this key statement. First, al-Banna starts his own discussion by putting the emphasis on 'sovereignty' whose transcendental nature the Brotherhood recognizes and strives to affirm. The idea that 'sovereignty belongs to God' (al hākimiyya li-l-lāh) constitutes a central signifier in the articulation of all Islamist discourses, and is rooted in traditional legal procedures. Naturally, this evidences the relevance of tradition as an imaginary horizon embodying an entire universe of signification. Fiqh (jurisprudence of Islamic law), shari'ah, social and legal norms regulating the 'personal status' of Muslims, 'Islamic theology', traditional discourses on jihad, traditional elements drawn from Sufism (spiritualism, organizational matters, etc.), references to the discourse of the caliphate and Islamic universalism-all constitute 'traditional' discursive fields from which al-Banna draws on when articulating his own discourse. Besides the symbolic relevance of tradition, however, another language plays a central role since this very beginning, inspiring al-Banna's discourse: modernity. At a general level, in fact, al-Banna strives to pursue an Islamization of modernity while, at the same time, modernizing tradition.

In consideration of al-Banna's assertion of God's sovereignty, for instance, its implementation by modern states is not only explained with the doctrinal argument of shari'ah incarnating the transcendental 'sovereign' power of God. It is also the self-sufficiency of Islam vis-à-vis competing systems of ideas that makes shari'ah, with its practical ability to solve human concrete needs, a natural source of legislation for the 'nation'.

Every nation has a set of laws in which the people partake their ruling. These sets of laws must be derived from the proscriptions of the Islamic Sharee'ah (drawn from the Noble Qur'an, and in accordance with the basic sources of Islamic jurisprudence). The Islamic Sharee'ah and the decisions of the Islamic jurists are completely sufficient, supply every need, and cover every contingency, and they produce the most excellent results and the most blessed fruits. ${ }^{48}$

Transcendence is here shadowed by the immanent ability of jurists' 'decisions' to respond to human needs, and to 'cover every contingency'. ${ }^{49}$ In later writings, when discussing the Islamic government, this point will be stressed in a much more energetic way. 
A second caveat is needed. In al-Banna's early writings, the tension between national and pan-Islamic drives remains largely unresolved. On the one side, a national perspective is sometimes assumed, though the conceptualization of the very idea of the nation remains mostly unexplored, acknowledged only as a matter of fact in the face of western imperialism. In an article written in 1933, al-Banna emblematically affirms the importance of the 'founding' of souls as functional primarily to the achievement of 'the nation's goals and aspirations':

The solution is the education and moulding of the souls of the nation in order to create a strong moral immunity, firm and superior principles and a strong and steadfast ideology. This is the best and fastest way to achieve the nation's goals and aspirations, and it is therefore our aim and the reason for our existence. It goes beyond the mere founding of schools, factories and institutions, it is the 'founding' of souls [insha' al-nufus ].

On the other side, a strong and clearly defined pan-Islamic ethos is articulated in al-Banna's early discourse, superseding national forms of loyalty. The result is that, at this stage, pan-Islamism and nationalism are roughly combined together, with pan-Islamism very often playing a pre-eminent role in terms of both conceptualization and celebration. In To What Do We Invite Humanity? al-Banna proclaims the universalistic nature of Islam as founded upon a notion of 'brotherhood'. As mentioned earlier, a Sufi influence affected al-Banna's conceptualization of the Society, largely as the result of the young al-Banna's involvement in a Sufi order. Such influence can be seen in the focus on the spiritual notion of 'brotherhood', as well as on symbolism, rites, the obedience and discipline of adherents (through the traditional oath of loyalty, bayat), the title and the strong charismatic tone assumed by al-Banna as the 'Supreme Guide' (al-murshid $a l$-'amm), and the spiritual emphasis in al-Banna's message. ${ }^{51}$ Tradition reflects therefore a central symbolic reservoir at this stage. The notion of Islamic brotherhood is particularly telling because it informs the criteria according to which the 'horizon of the Islamic homeland' is defined. It is the Islamic brotherhood, in the light of its intrinsic 'humanitarianism', that transforms the expansion of Islam into a movement for justice and equality, legitimizing such expansion, and distinguishing it from those forms of conquest and aggression based on mere 'geographic', 'ethnic' or 'racial' factors such as 'nationalism' and 'patriotism'. In a section entitled 'A Brotherhood Which Proclaims Humanitarianism', al-Banna states:

Whenever the light of Muhammad's (Peace Be Upon Him) guidance shone upon the souls of people, all differences were obliterated, wrongs were wiped out, justice and equality prevailed in their midst, along with love and brotherhood [...] The notion of nationalism thenceforth melts away and disappears just as snow disappears after bright, strong sunlight falls upon it. It is in contrast with the Islamic concept of brotherhood, which the Qur'an instils in the souls of all those who follow it. ${ }^{52}$

Being 'in contrast with the Islamic concept of brotherhood', the notion of nationalism is radically rejected here. Apparently, no attempt is made to integrate local nationalism within the broader universalistic framework expressed by the notion of Islamic homeland, as al-Banna will do later on. At this stage, a link is 
made instead between the notion of Islamic brotherhood and the need to preserve the 'territorial' integrity of Islam vis-à-vis its 'aggressors':

Islamic brotherhood compelled every Muslim to believe that every foot of ground supporting any brother who held to the religion of the Noble Qur'an was a portion of the larger Islamic homeland $[\ldots]$ For Islam, when it points this concept out to its people and fixes it firmly within their souls, imposes upon them the unavoidable obligation to protect the territory of Islam from the attack of the aggressor, to deliver it from occupation, and to fortify it against the ambitions of the transgressor. ${ }^{53}$

The strong anti-imperialist attitude that already marks the discussion at this stage reflects the embracing of a sort of re-active stance in al-Banna's words. The idea that the 'Islamic homeland' despite its transcendental and spiritual dimension is rooted in a 'territory' that its 'people' are 'obliged' to protect from 'the attack of the aggressor' indicates the adoption of a defensive stance vis-à-vis the infiltration of the West. This reflects Muslims' awareness during colonial times of western powers as physically penetrating into the Islamic homeland.

In this context, although the idea of the nation is not articulated and celebrated yet as a key component of al-Banna's discourse, he is aware of the hegemonic role that nationalist discourses play in the desedimented space of colonized populations. In the 1935 pamphlet, Our Message, al-Banna acknowledges the ability of nationalism to provide Muslims with an important tool in the fight for the political emancipation of the colonized world, therein enabling subaltern subjects to deploy western language against the West itself, e.g. in the form of Arab nationalism or Egyptian irredentism:

People are at times seduced by the appeal to patriotism, at other times by that of nationalism, especially in the East, where they are aware of the abuse that the colonial West directs against them, abuse which has injured their dignity, their honor, and their independence. ${ }^{54}$

In the attempt to appeal to the wide audience of nationalism, therein challenging the influence of the nationalist Wafd, al-Banna began in this pamphlet to come to term with the idea of the nation, for instance, by listing those aspects that were compatible with Islam and those that were incompatible; then, by maintaining that those that were compatible were indeed 'prescribed' by what could be defined the master signifier 'Islam'; that is, the central element around which all signifiers (discursive components) of a certain discourse converge, so achieving their particular significance. 55 When describing 'patriotism' and 'nationalism', for instance, he stated that if these concepts mean 'affection' ('love for one's homeland'), 'freedom and greatness' ('every effort to free the land from its ravagers, to defend its independence'), 'community' ('to reinforce the bonds which unite individuals within a given country'), 'conquest' ('the conquest of countries and sovereignty over the earth') — then 'Islam has already ordained that'. He pointed out, however, that if patriotism and nationalism meant 'factionalism', 'aggression' ('racial self-aggrandizement to a degree which leads to the disparagement of Other races'), and 'fanaticism' (the revival of pre-Islamic customs) - then they were incompatible with Islam. As he put it: 


\section{ANDREA MURA}

The bone of contention between us and them [western powers] is that while we define patriotism according to the creed of Islam, they define it according to territorial borders and geographical boundaries. ${ }^{56}$

Although nationalism is not yet assumed as a central component in the discourse of al-Banna, we see here a first attempt to acknowledge the relevance of 'national' signifiers, showing that Islamism works on the side of national independence. National elements are therefore partially integrated, though still in an unbalanced manner. For instance, on the one side, al-Banna rejects here local forms of nationalism, like 'Pharaonism, Arabism, Phoenicianism, or Syrianism', and on the other side, he states immediately after that:

Nevertheless, we are not denying that the various nations have their own distinct qualities and particular moral characters [...] We believe that in these respects Arabism possesses the fullest and most abundant share, but this does not mean that its peoples should seize upon these characteristics as a pretext for aggression. ${ }^{57}$

The strategic attempt to address a youth particularly sensitive to the national claim, as well as to a strong form of irredentism, is evident. ${ }^{58}$ It is emblematic that al-Banna, for instance, aims to re-assure those nationalist sceptics that fear Islamism for its potential to divide the 'nation' because of religious issues:

I would like to draw your attention to the glaring error in the leading figure who says: that acting on this principle [Islam] would tear apart the unity of the nation, which is composed of different religious elements [...] Do you not now see exactly how much we are in agreement with the most ardent patriots regarding love of the country's well being, sincere struggle for the sake of its liberation, its welfare, and its progress. ${ }^{59}$

In summary, although national signifiers at this stage were acknowledged, they were not yet celebrated as central to al-Banna's articulation. That is, a universalistic ethos here was still privileged, promoting a certain criticism towards the more 'un-Islamic' aspects of nationalism (the western focus on ethnicity and borders vis-à-vis the Islamic ability to preserve an inclusive spiritual fraternity).

\section{The late 1930s}

It is in the late 1930s that al-Banna's drawing on the language of modernity was translated into a stronger integration and celebration of national signifiers. This testified to a gradual 'nationalization' of al-Banna's own premises, with the progressive adoption of a binary understanding of both territoriality and community. Such a twist reflected al-Banna's growing awareness of the massive appeal that nationalism was able to elicit in the region, with local populations more and more frustrated by the persisting control of British over Egyptian affairs. ${ }^{60}$ Naturally, this was also a response to the international arena and the difficult climate preceding World War II. In Egypt, the hope to exploit the tension among European nations to gain full independence had, in fact, contributed to stir nationalist feelings. ${ }^{61}$ It should be noted, however, that such a transition in al-Banna's articulation did not entail the dismissal of tradition. 
Traditional elements were, in fact, still combined with national elements, therein allowing for a counter-hegemonic deployment of the national language. As Lia puts it, the Brotherhood's ideological vision in these years 'served in many ways as a bridge between the traditional and modernist camps by its insistence on Islam as its only ideological tenet, but incorporating at the same time many aspects of modern ideologies and thinking. ${ }^{62}$ This moderator function can be seen, for instance, in the notion of a multi-level identity elaborated by al-Banna in the 1937 pamphlet, Towards the Light. ${ }^{63} \mathrm{We}$ find here the first systematic integration of the idea of the nation within a harmonious multi-dimensional model where pan-Islamic views are merged together with national signifiers. For the first time, al-Banna defines the Islamic homeland as consisting of:

(1) The country itself.

(2) The other Islamic countries, for all of them are seen as a home nation and an abode for the Muslim.

(3) This extends to the first Islamic Empire [...]

(4) Then the homeland of the Muslim expands to encompass the entire world. ${ }^{64}$

This passage is of paramount importance since it signals the transition to a formal recognition of nationalism-even in its local forms of loyalty. The 'country' is taken here as a basic component of a wider 'homeland of the Muslim'. Therefore, al-Banna promotes a first clear articulation of national signifiers with the master signifier 'Islam'; as al-Banna puts it in the same pamphlet: 'thus did Islam reconcile the sentiments of local nationalism with that of a common nationalism, in all that is good for mankind.' More than simply acknowledging the existence of nationalism or its importance vis-à-vis foreign occupation, al-Banna here integrates nationalism as a new 'moment' in the discourse of Islam. By theorizing identity as the complex overlapping of greater concentric circles, each one denoting a form of loyalty ('the country itself' denoting the national loyalty, 'the first Islamic Empire' denoting the Arab circle, and then the 'other Islamic countries' entailing also an eastern and a global conception of 'Islamic homeland'), al-Banna begins celebrating modern nationalism, interpreting it in the light of the purifying force of Islam.

If the nation possesses all these reinforcements: hope, patriotism, science, power, health, and a sound economy, it will, without a doubt, be the strongest of all nations, and the future will belong to it. Especially, if to all this one adds that it has been purified of selfishness, aggressiveness, egotism, and arrogance, and has come to desire the welfare of the whole world. ${ }^{65}$

In this pamphlet, al-Banna maintains and promotes most of the features that modern nations were expected to develop in that specific historical time, thereby reproducing nationalist discourses on 'national greatness', 'militarism', 'public health', 'science', 'economics', etc. In the attempt to Islamize modernity, celebrating the purifying power of Islam towards modernity itself, al-Banna, 
however, points also to a series of moral problems related to modernity that Muslim nations would be able to avoid when grounded in Islam:

Along the path of Europe are to be found enticement and glamour, pleasures and luxuries, laxity and license, and comforts that captivate the soul, for all of these things are loved by the soul [...] But the path of Islam is one of glory and fortitude, truth, strength, blessing, integrity, stability, virtue, and nobility. Take the nation along this path, may Allah grant you success! $!^{66}$

Interestingly, we can note that al-Banna's re-active appropriation of modernity is preserved in the earlier passage and expressed through the deployment of an Occidentalist narrative.

As well known, in the remarkable work of Edward Said, Orientalism was conceived as the western systematic depiction of Oriental societies and cultures fostered by a long-standing production of political, literary, anthropological literature on the Orient. ${ }^{67}$ It methodically merged forms of power and knowledge based on binaries and essentialisms into a practice functional to both western colonial expansion and the very definition of European identity (and modern subjectivity).

In al-Banna's discourse, Occidentalism entailed the attempt to reverse Orientalist binary representations redefining the Orient from a privileged position. Reductionisms and essentialisms are here used to reverse the logocentric approach deployed by Orientalist discourses-Islam becoming therefore the place of 'integrity, stability, virtue, and nobility' and resurgence in the face of western 'enticement and glamour, pleasures and luxuries, laxity and license' and moral decline. Such representation may be conceived through what Sartre called the moment of the boomerang, a strategy aimed at counterbalancing the positive dialectic of colonialism with an opposing revolutionary and negative dialectic. ${ }^{68}$

In this regard, it is interesting to note that since the pamphlet, To What Do We Invite Humanity? the Oriental East is not rejected on the ground of being a European and abstract concept; rather, the Islamic East is acknowledged a number of times and positivized in the face of the western Other. This reproduces the very dialectical mindset that informed the colonial discourse, even though this is done from an anti-imperialist perspective. Hence, al-Banna's reactive emphasis on the notion of the East, with statements such as 'the East would rise up and compete with the nations which have stolen its rights and oppressed its people. ${ }^{69}$ This approach entails the counter-hegemonic attempt to dislocate the western monopoly over modern political paradigms, articulating modern 'signifiers' around the master signifier 'Islam'. Thus, the orientalist negative term 'East' is positivized by the very articulation of the master signifier Islam: "the foundations of modern Eastern resurgence [emphasis mine] are built on the basic principles of Islam. ${ }^{70}$

The increasing appropriation of the language of modernity is also manifest in the following pamphlet, Between Yesterday and Today (1939), where Islam itself appears as a unified nation satisfying both material and spiritual needs:

There is no nation in the world that is held together by linguistic unity, participation in material and spiritual interests, and similarity of both suffering and hope that the Muslims are. $^{71}$ 
Interestingly, a peculiarity of the Islamic nation is located here in its 'linguistic unity'. We see that despite al-Banna's criticism of western racial and territorial nationalism, Arab language and ethnicity are somehow exalted and posited as the very foundation of the Islamic community. A passage best illustrates this point:

The transfer of authority to non-Arabs: Persians at one time, the Mamluks, Turks, and others at another time who had never had a taste of genuine Islam, and whose hearts had never been illuminated with the light of the Qur' an because of the difficulty they encountered in trying to grasp its concepts, even though they read the Words of Allah. ${ }^{72}$

In a speech delivered during the Fifth Conference of the Brotherhood in 1939, also printed as a pamphlet under the title Oh Youth, al-Banna reiterates such points. ${ }^{73}$ Besides reasserting his distance from any form of racial discrimination, and criticizing those 'international agreements that have torn the Islamic nation into small and weak mini-states that can easily be swallowed by their aggressors,' he directly calls for the 'national loyalty' of all Muslims for their homeland in their fight against foreign power. ${ }^{74}$ Defence must follow then the multi-dimensional complexity of Muslim identity. This entails that a primary focus be put on the fight for independence of one's country, followed by broader loyalty towards the whole Islamic homeland:

Muslims strive hard for a motherland such as Egypt, exert their utmost effort for its cause and exhaust themselves in the Jihad because Egypt is a part of the Islamic land and the leader of its nations. Moreover, Muslims do not confine these sentiments within its limits, but they enjoin within these sentiments each Islamic land and nation. ${ }^{75}$

This passage well illustrates al-Banna's position at the end of the 1930s, with Egyptian nationalism acknowledged and combined with a pan-Islamic ideal, 'Egypt is a part of the Islamic land', yet increasingly celebrated at the point of justifying the 'utmost effort for its cause' as 'the leader of its [Islamic] nations'. In the following years, it will be possible to observe an even greater valourization of national signifiers.

\section{Al-Banna's discourse in the 1940s: the national priority}

By the end of the 1930s, the Brotherhood had become the most influential mass movement in Egypt, followed only by the Wafd whose political appeal, however, was gradually declining. ${ }^{76}$ From the beginning of the 1940 s, the idea of an Islamic government received more attention from al-Banna in a way that sometimes superseded the early emphasis on the Islamization from below. In a pamphlet that appeared in the early 1940s, The Message of the Teachings, after having defined the aspirations of the Brotherhood as aimed at reforming the self, establishing Islam as an 'ideology' which calls for 'righteousness' and encourages 'virtue', and which strives to liberate the homeland 'from all un-Islamic or foreign control', al-Banna expressly advocates:

Reforming the government so that it may become a truly Islamic government, performing as a servant to the nation in the interest of the people. By Islamic government I mean a 
government whose officers are Muslims who perform the obligatory duties of Islam, who do not make public their disobedience, and who enforce the rules and teachings of Islam [...] Rebuilding the international prominence of the Islamic Umma by liberating its lands [...] until once again the long awaited unity and the lost Khilafah is returned. ${ }^{77}$

Besides the highly rhetorical and irredentist tone of this quotation, asking for the liberation of the Islamic homeland and the restoration of the caliphate ('the lost Khilafah is returned'), the significance of this passage is that al-Banna defines in clear terms what he means by Islamic government. ${ }^{78}$ It is interesting to note that while defining Islamic government as a Muslim administration, where officers are Muslims and where Islamic rules and teachings are enforced, the language used to articulate such an administration is a nationalist one, for 'a truly Islamic government' is the one 'performing as a servant' to 'the nation' in the 'interest' of the 'people', that is, neither in the interest of Islam itself nor in that of shari'ah. This is a point of pivotal importance for it signals a kind of adaptation of the Islamic government to the nation-state model in al-Banna's discursive trajectory, though this adaptation was not new in absolute terms.

Since the late 19th century, the encounter between the language of modernity and the language of tradition had given rise to an ongoing debate about the nature of the Islamic government. Crucially, a great reformist like Muhammad 'Abduh (1849-1905) had used the legal notion of maslaha, the 'common good' in Islamic jurisprudence, to re-consider the traditional prerogatives of the government, influencing the cultural climate preceding the foundation of the Brotherhood in the 1920 s. $^{79}$ Since the 13th century, the concept of maslaha had undertaken important conceptual shifts, allowing for doctrinal innovations (I mentioned earlier that the principle of maslaha was used by Shafi'i jurists to moderate universalistic polarity introducing the domain of dar al-'ahd). ${ }^{80}$ Al-Banna's focus on 'the interest of the people' came to sanction these ongoing cultural transformations, bringing the Islamic notion of 'common good' - which had to maintain some moral and theological characterization as expression of the will of God-close to the liberal concept of 'public interest' or 'general welfare', to use Robert Mitchell's translation of this term. ${ }^{81}$

When describing the constitutive features of the discourse of the nation, I mentioned that a common juridical tendency among European modern doctrines of sovereignty had been to conceptualize the supreme power of political order as an absolute and exclusive power that does not recognize any principle of legitimacy outside itself (summa potestas). In particular, modern sovereignty entailed the passage of this exclusive and absolute power from the transcendent dimension of God to the immanent authority of the state, though differences among theorists regarded the locus of sovereignty: the king, the people, the law, etc. In the previous pages, it was noted that while acknowledging the transcendent power of God in principle, al-Banna's transcendent advocacy was shadowed on a practical level by the emphasis he put on the immanent ability of jurists' 'decisions' to 'cover every contingency'. ${ }^{82}$ The earlier passage intensifies this early emphasis on the immanent character of sovereignty, defining a 'truly Islamic 
government' 'as a servant to the nation in the interest of the people [emphasis mine]'. It is not God or shari'ah that defines the ultimate 'interest' of which the Islamic government is an expression, but 'the people', here incarnating the locus of sovereignty and the space of public interest. This signals the integration and re-elaboration of modern national signifiers and the substantial resonance with modern theories of sovereignty of the state, in itself a further expression of al-Banna's re-elaboration of the language of modernity.

This transition defines al-Banna's representation of the Islamic order as a sort of modern nation-state, deprived of its secular characterizations, with shari'ah inspiring legislative provisions rather than literally supplanting them. Such a position is testified to by al-Banna's increasing opening to western parliamentary political and institutional procedures in the early 1940s. Although on several occasions al-Banna had rejected the party system as a factor of social and political division ('we do not support these political parties'), and invited Muslims 'to boycott non-Islamic courts and judicial systems' that draw on western juridical principles, he acknowledged liberal tools in principle (for instance, the separation of powers, or state institutions such as the Parliament). ${ }^{83} \mathrm{He}$ formally engaged, for instance, in the mainstream political process, even advancing his candidature to the parliamentary election of $1942 .{ }^{84}$ Although his candidature was withdrawn under pressure from the King and the Wafd in exchange for the promise to introduce some 'Islamic laws' prohibiting gambling and prostitution, this event reveals that al-Banna had begun considering the modern state as offering all the tools needed for the implementation of an Islamic system. More precisely, the Islamization of the modern statist structure was seen as an antidote to the dangers of the secular state. Later on in the 1940s, while describing the 'course of modernity', al-Banna praised the emancipatory nature of the democratic system, alerting the reader, however, to the risks entailed by modernity.

The democratic system led the world for a while, encouraging many intellectuals as well as the masses to think of it as the ideal system. Nobody can ignore the freedom it has secured for peoples and nations alike, and the justice it has introduced to the human mind in allowing it to think freely [...] However, it was not long before people realized that individuality and unlimited liberty can lead to chaos and many other short-comings, which ultimately led to the fragmentation of the social structure and family systems, and the eventual re-emergence of totalitarianism. ${ }^{85}$

Al-Banna's use of modern language is exemplary here. Central to the point is his emphasis on the risks of modern individualism (here described in terms of 'individuality') and the ultimate 'fragmentation of the social structure and family systems'. Since the 19th century, a long-standing speculative tradition in Europe had assumed moral disquiets such as individualism, atomism, alienation, relativism and materialism to be eminently 'modern' features, therein contributing to consolidate a sort of moral connotation of modernity (von Humboldt, Tocqueville, Durkheim, etc.). In this sense, al-Banna fully reflects the attempt to appropriate the language of modernity for counter-hegemonic purposes, pointing to the modern loss of sociability that had hitherto been associated with the 
emergence of industrial societies. Hence, al-Banna's emphasis on Islamic 'brotherhood' as a remedy against the 'fragmentation' of 'family systems', 'social structure' and community is in line with modern social criticism.

At this stage, al-Banna's recognition of local nationalism as an integral part of dar al-Islam is fully achieved. In a passage, al-Banna makes his own devotion towards Egyptian nationalism explicit:

Egyptian nationalism has a definite place in our call. It is its right that it should be defended. Surely we are Egyptians; the most honourable place on this Earth to us, we were born and raised up here. Egypt is the land, which has been an abode of belief. It gladly embraced Islam and gave it a new territory [...] This is only a part of the entire Arab homeland. Therefore, whatever effort we make for the welfare of Egypt, would in reality be for Arabia, The East and Islam. ${ }^{86}$

We see that al-Banna re-articulates nationalism preserving the idea of the nation, and transforming it into an expression of Islamic loyalty: "whatever effort we make for the welfare of Egypt, would in reality be for Arabia, The East and Islam'.

In the 1940s, the idea of the growing concentric circles (each one referring to a specific form of identification, e.g. Egyptian, Arab, Eastern, Islamic) that was first expressed in Towards the Light in 1937 became an integral part of al-Banna's discursive articulation. We have just seen in the last two lines of the previous quote that al-Banna clearly links Egyptian nationalism, and the effort made for the sake of national independence to the upper levels of loyalty, to the upper strata of the Islamic homeland. Each of these circles maintains its modern binary structure when defining space and subjectivity, for instance, by relying on an exclusionary notion of 'territory' or defining 'people' as a unified community grounded on common 'history', 'religion' and 'language'. This is best demonstrated by al-Banna's conceptualization of Arab subjectivity in the Arab circle:

Islam cannot be revived, unless the Arabs start to revive and become a unified force. It is for this reason that we regard every inch of the native land of the Arabs as part of our own homeland. How can these geographical boundaries and political divisions, terminate the value and feelings of the Arabic/Islamic Unity, which united in the hearts of myriads, one hope and one goal, turning all these countries into one nation $?^{87}$

In the previous section, I argued that the binary structure organizing nationalism entailed the transformation of local populations into a nation, that is, the subsumption of all differences into a unified 'self', the national people, which was furthermore put in radical opposition with its outside (competing nations). The earlier passage is particularly telling in this respect. Al-Banna acknowledges that differences inform the contemporary reality of 'Arabs', but he advocates the need to overcome such divisions becoming 'a unified force', to 'unite in the hearts of myriads, one hope and one goal, turning all these countries into one nation'. It is the movement of national unification that transforms the various Arab populations into a people, and that allows Islam to 'be revived'. 
The general adoption of a binary logic is also reflected in the Occidentalist representation of the 'East' as a unified Self, opposed to a western outside accused of invading the 'orient'. In the 1940s, the strategic and reactive function of Occidentalism that aimed at reversing Orientalist discourses is openly professed:

Orientalism: This also has a position in our invitation, although it is based entirely on ephemeral and transitory things. It so happened that the West became unduly proud of its civilisation. Accordingly, it abandoned and isolated the Eastern nations, dividing the world into two parts: one was named the East, and the other, the West $[\ldots]$ This made the Easterners feel that they were one battalion, ready to meet the ranks of the West. ${ }^{88}$

It is interesting to note that Occidentalism fully reverses the logocentric approach of Orientalist discourses. The 'East' is here positivized against the West from which it was 'abandoned and isolated'. This is done, again, by subsuming differences within a higher unity set against an outside, that is, transforming a plurality of Eastern manifestations into 'one battalion'. Occidentalism is therefore a further example of the importance that al-Banna ascribed to binary representations, revealing, as described throughout this section, an increasing valourization of the modern symbolic reservoir.

We see here that the idea of the nation is integrated and maintained as a strategic device in the discourse of al-Banna. The celebration of local nationalism as a first, more intimate circle within broader forms of loyalty (Arab, Eastern, Islamic), the very structure used to construct any of the identity circles that al-Banna foresees (as if the Arab, the Eastern and the Islamic circles are national circles in their own right)(all this denotes the delineation of a territorial trajectory. This entails the adoption of a binary logic defining forms of space (territory) and subjectivity (people), with tradition maintained nonetheless as a moderator principle in the counter-hegemonic process of re-signifying the space of modernity from a counterhegemonic perspective.

\section{Conclusion}

This article inquired into the discourse of Islamist thinker and militant Hasan al-Banna. I first provided the reader with a historical contextualization of al-Banna's times, and then proceeded to a textual examination of his writings. I showed here that al-Banna's discourse was initially caught between nationalism and panIslamism, two discourses defining al-Banna's genealogical discursive context and characterizing the desedimented space of Middle Eastern colonized settings.

Despite the moderator function of tradition, I showed that nationalism ended up fulfilling a central symbolic function across the years. Since the 1940s, al-Banna's recurrent reference to Egypt as a leader of Muslim nations, and his idea that the fight for Egyptian independence must precede any other political struggle, testified to the increasing importance of the nationalist model in his discourse. Besides evidencing the strategic attempt to face the challenges of a colonized context, this reliance on a nationalist model reflected the ultimate adoption of a binary approach to space representations and subjective formations, denoting what 
could be termed a 'territorial' trajectory of Islamism. This was best revealed by al-Banna's immanent approach to sovereignty, with the 'interest of the people' posed as the prior requirement for any 'truly Islamic government'. Al-Banna's notion of Islamic 'government' or 'system' (al-nizam al-Islami) paved the way to the theorization of an Islamic state that was central in the political agenda of Islamist groups in the following decades, the Brotherhood included. The nationalization of al-Banna's discourse, however, signalled that the target was not the restoration of a traditional Islamic government but rather a sort of counter-hegemonic appropriation and Islamization of the nation-state structure, with shari'ah maintained as an ethical source for state legislation.

From a general level, al-Banna's trajectory reveals that the nationalization of the Islamist message was somehow intrinsic to the very discursive development of early Islamist representations, rather than emerging as a sort of political expedient in recent decades. Although one should acknowledge that significant differences have come to characterize the Islamist galaxy across the years, with globalist and universalistic tendencies being revitalized among several groups and theorists, this is certainly true as far as a territorial trajectory of Islamism is concerned, one that finds in al-Banna a kind of foundational discourse. This is the case with the Brotherhood, which remained in some respects a creature of its founder even after its leader's death occurred in 1949 under the alleged instruction of the government's secret police. ${ }^{89}$ But al-Banna's vision remained an 'exemplary' way of engaging with symbolic reservoirs such as modernity and tradition for all those groups that, in different manners and with various degrees of intensity, have assumed the Brotherhood as a 'proto-typical' Islamist movement. For all these groups is true what Peter Mandaville observed in his analysis of contemporary Islamism, that they all 'owe a debt to the project Hasan al-Banna initiated in 1928.' 90

\section{Notes and References}

1. F. A. Gerges, The Far Enemy: Why Jihad Went Global (Cambridge: Cambridge University Press, 2005); D. R. Springer, Islamic Radicalism and Global Jihad (Washington, DC: Georgetown University Press, 2008); O. Roy, Globalized Islam-Fundamentalism, Deterritorialization and the Search for a New Ummah (London: Hurst, 2004).

2. G. Kepel, Jihad: The Trail of Political Islam (London: I.B. Tauris, 2002), and O. Roy, The Failure of Political Islam (London: I.B. Tauris, 1994).

3. M. Ayoob, The Many Faces of Political Islam: Religion and Politics in the Muslim World (Ann Arbor, MI: University of Michigan Press, 2008).

4. M. Colombe, L'Évolution de l'Égypte-1924-1950 (Paris: G.P. Maisonneuve et Cie, 1951).

5. I. Sedar and H. J. Greenberg, L'Egypte entre deux mondes (Paris: Carrefours Du Monde, 1956).

6. G. R. Warburg, Egypt and the Sudan-Studies in History and Politics (London: Frank Cass, 1985); W. Yale, The Near East-A Modern History (Ann Arbor, MI: University of Michigan Press, 1953).

7. G. M. Muñoz, Politica y Elecciones en el Egipto Contemporaneo-1922-1990 (Madrid: Agencia Española de Cooperación Internacional, Instituto de Cooperación con el Mundo Arabe, 1992).

8. M. Deeb, 'Continuity in modern Egyptian history: the Wafd and the Muslim brothers', in AAVV (Ed.) Problems of the Modern Middle East in Historical Perspective: Essays in Honour of Albert Hourani (Reading: Ithaca Press, 1992).

9. S. Haj, Reconfiguring Islamic Tradition: Reform, Rationality, and Modernity (Stanford, CA: Stanford University Press, 2009), p. 4.

10. T. Asad, The Idea of an Anthropology of Islam (Washington, DC: Center for Contemporary Arab Studies, Georgetown University), p. 14. 
11. Colombe, L'Évolution de l'Égypte, op. cit., Ref. 4.

12. M. Q. Zaman, The Ulama in Contemporary Islam: Custodians of Change (Princeton, NJ: Princeton University Press, 2002), p. 4.

13. E. Laclau, New Reflections on the Revolution of Our Time (London: Verso, 1990).

14. D. E. Lee, 'The origins of pan-Islamism', The American Historical Review, 47(2) (January 1942), p. 280.

15. N. R. Keddie, An Islamic Response to Imperialism: Political and Religious Writings of Sayyid Jamāl ad-Dīn 'al-Afghānī' (Berkeley, CA: University of California Press, 1983).

16. M. Parvin and M. Sommer, 'Dar al-Islam: the evolution of Muslim territoriality and its implications for conflict resolution in the Middle East', International Journal of Middle East Studies, 11(1) (February 1980), p. 18.

17. M. Khadduri, The Islamic Law of Nations: Shaybani's Siyar (Baltimore, MD: Johns Hopkins Press, 1966), p. 13.

18. Khadduri, ibid., p. 232.

19. B. Lewis, The Political Language of Islam (Chicago, IL/London: University of Chicago Press, 1988).

20. It is interesting to note that, in face of the increasing fragmentation of Islamic political power, the unifying and universalistic symbolic appeal of the caliphate remained substantially intact. The Ottomans, for instance, had to promote the myth of a formal passage of the caliphate from the last descendant of the Abbasids to them to legitimize their declining power during the 18th century; cf. K. H. Karpat, The Politicization of Islam: Reconstructing Identity, State, Faith, and Community in the Late Ottoman State (New York/Oxford: Oxford University Press, 2001).

21. T. Barghuthi, The Umma and the Dawla: The Nation State and the Arab Middle East (London: Pluto Press, 2008).

22. T. Asad, Formations of the Secular: Christianity, Islam, Modernity (Stanford, CA: Stanford University Press, 2003), p. 197.

23. Asad, ibid., p. 197.

24. P. Virno, A Grammar of the Multitude: For an Analysis of Contemporary Forms of Life (Los Angeles, CA: Semiotext(e), 2004).

25. J. Bodin, On Sovereignty: Four Chapters from the Six Books of the Commonwealth (Cambridge: Cambridge University Press, 1576/1992); T. Hobbes, Leviathan (Oxford: Oxford University Press, 1651/1998).

26. B. Anderson, Imagined Communities: Reflection on the Origin of the Spread of Nationalism (London: Verso, 1983).

27. E. Balibar, 'Racism and nationalism', in E. Balibar and I. Wallerstein (Eds) Race, Nation and Class (London: Verso, 1991), and R. Young, Colonial Desire: Hybridity in Theory, Culture and Race (London: Routledge, 1995).

28. G. Delanty, Inventing Europe: Idea, Identity, Reality (Basingstoke: Macmillan, 1995).

29. M. Foucault, Security, Territory, Population: Lectures at the Collège de France, 1977-1978 (Basingstoke: Palgrave Macmillan, 2007).

30. G. Marramao, Passaggio a Occidente (Torino: Bollati Boringhieri, 2003).

31. M. Purcell, 'Place for the copts: imagined territory and spatial conflict in Egypt', Ecumene, 5(4) (1998), p. 433.

32. A. Norval, 'Trajectories of future researches in discourse theory', in D. Howarth, A. Norval and Y. Stavrakakis (Eds) Discourse Theories and Political Analysis (Manchester: Manchester University Press, 2000).

33. S. Reimer, 'Benedict Anderson', in P. Hubbard, R. Kitchin and G. Valentine (Eds) Key Thinkers on Space and Place (London/New York: Sage, 2004), p. 20.

34. J. Heyworth-Dunne, Religious and Political Trends in Modern Egypt (Washington, DC: Author, 1950); C. P. Harris, Nationalism and Revolution in Egypt-The Role of the Muslim Brotherhood (The Hague: Mouton \& Co., 1964); R. Mitchell, The Society of the Muslim Brothers (London: Oxford University Press, 1969).

35. I. M. al-Husayni, The Moslem Brethren-The Greatest of Modern Islamic Movements (Beirut: Khayat's College Book Cooperative, 1956); B. Maréchal, The Muslim Brothers in Europe: Roots and Discourse (Leiden/ Boston, MA: Brill, 2008).

36. B. Lia, The Society of the Muslim Brothers in Egypt-The Rise of an Islamic Mass Movement 1928-1942 (London: Ithaca Press/Garnet Publishing, 1998).

37. F. Bertier, 'L'idéologie politique des frères musulmans', Orient, VIII (1958); I. M. Abu-Rabi, Intellectual Origins of Islamic Resurgence in the Modern Arab World (Albany, NY: State University of New York Press, 1996); A. S. Moussalli, 'Hasan Al-Banna's Islamist discourse on constitutional rule and Islamic state', Journal of Islamic Studies, 4(2) (1993), pp. 43-57. 


\section{ANDREA MURA}

38. T. Ramadan, Aux sources du renouveau musulman: d'al-Afghani à Hasan al-Banna, un siècle de réformisme islamique (Paris: Bayard Editions/Centurion, 1998); A. Abdel-Malek, La pensée politique arabe contemporaine (Paris: Editions du Seuil, 1970).

39. F. Rosenthal, 'The "Muslim brethren" in Egypt', Muslim World, XXXVIII (October 1947); I. Gershoni and J. P. Jankowski, Redefining the Egyptian Nation, 1930-1945 (Cambridge: Cambridge University Press, 1995), pp. 278-91.

40. O. Carré and M. Seurat, Les frères musulmans (1928-1982) (Paris: L’Harmattan, 1983); G. Kepel, Muslim Extremism in Egypt: The Prophet and Pharaoh (Berkeley/Los Angeles, CA: University of California Press, 1984).

41. A. al-Fattah el-Awaisi, 'The conceptual approach of the Egyptian Muslim brothers: towards the Palestine question, 1928-1949', Journal of Islamic Studies, 2(2) (1991); I. Gershoni, 'The Muslim brothers and the Arab Revolt in Palestine, 1936-1939', Middle Eastern Studies, 22 (1986).

42. The most organic and general treatise, comprising biographical and some ideological discussion, is al-Banna's memoir, Memoirs of the Call and the Preacher (Mudhakkirat al-Dawa wa al-Daiya) (Cairo: Dar al-Tawzi’ wa al-Nashr al-Isamiyya, 1947/1986), (first parts published in instalments in 1942). Most of the themes discussed in his memoirs, however, were anticipated in his rasals, 'letters' traditionally assuming the form of religious treatises which were used by al-Banna to address specific topics (translated either as 'tracts' or as 'pamphlets'). The following textual examination will consider most of the rasals he wrote across the years.

43. Italics will be used in this section to stress specific points I want to emphasize or, alternatively, when typing words in languages other than English. Single quotation marks will be deployed to quote al-Banna's own words as found in the original text.

44. Harris, Nationalism and Revolution in Egypt, op. cit., Ref. 34.

45. H. al-Banna, 'Da'wa ila Allah', Majallat al-Fath, $\mathrm{n}^{\circ} 100,1346 / 1928$, in Lia, The Society of the Muslim Brothers in Egypt, op. cit., Ref. 36, p. 33.

46. H. al-Banna, To What Do We Invite Humanity? (Cairo: n.p., 1934); Also appeared as a pamphlet in 1936, available at http://thequranblog.files.wordpress.com/2008/06/_2_-to-what-do-we-invite-humanity.pdf (accessed March 2011).

47. al-Banna, ibid.

48. al-Banna, ibid.

49. A. S. Moussalli, for instance, notes that although al-Banna's 'political discourse is abstract and uncompromising as in proposing the necessity and legitimacy of God's hakimiyya, his method, because it is conducted by humans, is practical and compromising', op. cit., Ref. 37, p. 169.

50. H. al-Banna, 'Aghrad al-Ikhwan al-Muslimin', Jaridat al-Ikhwan al-Muslimin, 7(1352/1933), in Lia, The Society of the Muslim Brothers in Egypt, op. cit., Ref. 36, p. 67.

51. On the influence of Sufism in moulding the spiritual character of the Brotherhood, see Lia, ibid., p. 116; For a discussion about al-Banna's early involvement in Sufi orders, see al-Husayni, The Moslem Brethren-The Greatest of Modern Islamic Movements, op. cit., Ref. 35, pp. 28-30; E. Pace, Sociologia dell'Islam-Fenomeni religiosi e logiche sociali (Roma: Carocci, 1999), p. 178.

52. al-Banna, To What Do We Invite Humanity? op. cit., Ref. 46.

53. al-Banna, ibid.

54. H. al-Banna, 'Da'watuna' (our message), in Jaridat al-Ikhwan al-Muslimin (1353/1935); Also appeared as a pamphlet in 1937, available at http://thequranblog.files.wordpress.com/2008/06/_6_-our-message.pdf (accessed March 2011).

55. B. S. Sayyid, A Fundamental Fear: Eurocentrism and the Emergence of Islamism (London: Zed Books, 1997).

56. al-Banna, 'Da'watuna', op. cit., Ref. 54.

57. al-Banna, ibid.

58. The attempt to attract students and young adherents was also translated in the creation of a number of paramilitary bodies in these years, including a 'military wing' or 'secret section'; Lia, The Society of the Muslim Brothers in Egypt, op. cit., Ref. 36, pp. 170-175. For the influence of Fascist and Nazi paramilitary organisations in the creation of these bodies, see al-Husayni, The Moslem Brethren-The Greatest of Modern Islamic Movements, op. cit., Ref. 35.

59. al-Banna, 'Da'watuna', op. cit., Ref. 54.

60. It should be noted that a crucial event in these years had been the Anglo-Egyptian Treaty of 1936, which paved the way to the abolition of the capitulations in Egypt, reinvigorating the problem of a 'substantial' national independence as the centre of political debate; W. M. Abdelnasser, The Islamic Movement in Egypt-Perceptions of International Relations 1967-1981 (London: Kegan Paul International, 1994).

61. G. Kirk, The Middle East in the War (London: Royal Institute of International Affairs, 1952). 


\section{A GENEALOGICAL INQUIRY INTO EARLY ISLAMISM}

62. Lia, The Society of the Muslim Brothers in Egypt, op. cit., Ref. 36, p. 74.

63. H. al-Banna, Towards the Light (Cairo: Dar al-Kitab al-Arabi, 1936), available at http://thequranblog.files. wordpress.com/2008/06/_1_-toward-the-light.pdf (accessed March 2011).

64. al-Banna, ibid.

65. al-Banna, ibid.

66. al-Banna, ibid.

67. E. Said, Orientalism (Harmondsworth: Penguin, 1978/1995).

68. With this expression, the French philosopher used to refer, in political and practical terms, to the African movement of negritude; see J.-P. Sartre, 'Preface', in F. Fanon (Ed.) The Wretched of the Earth (New York: Grove Press, 1963), p. 20.

69. al-Banna, To What Do We Invite Humanity? op. cit., Ref. 46.

70. al-Banna, ibid.

71. H. al-Banna, Between Yesterday and Today (Cairo: n.p., 1939), available at http://thequranblog.files. wordpress.com/2008/06/_7_-between-yesterday-today.pdf (accessed March 2011).

72. al-Banna, ibid.

73. H. al-Banna, Oh Youth (pamphlet, 1939), available at http://thequranblog.files.wordpress.com/2008/06/ 9_-oh-youth.pdf (accessed March 2011).

74. al-Banna, ibid.

75. al-Banna, ibid.

76. This period coincided also with the Brotherhood's expansion in terms of organization and popularity; see Lia, The Society of the Muslim Brothers in Egypt, op. cit., Ref. 36.

77. H. al-Banna, The Message of the Teachings (Cairo: n.p., appeared in the early 1940s), available at http:// thequranblog.files.wordpress.com/2008/06/_3_-the-message-of-the-teachings.pdf (accessed March 2011).

78. On al-Banna's ideas on the caliphate, see Bertier, 'L'idéologie politique des frères musulmans', op. cit., pp. 161-174.

79. W. B. Hallaq, A History of Islamic Legal Theories: An Introduction to Sunni Usul al-Fiqh (Cambridge: Cambridge University Press, 1997).

80. F. Opwis, 'Maslaha in contemporary Islamic legal theory', Islamic Law and Society, 12(2) (2005), pp. $182-223$.

81. Mitchell, The Society of the Muslim Brothers, op. cit., Ref. 34, p. 239.

82. al-Banna, To What Do We Invite Humanity? op. cit., Ref. 46.

83. al-Banna, The Message of the Teachings. See M. Borrmans, 'Les Fréres Musulmans', Comprendre, 70 (XIV) (April 1969), pp. 14-25.

84. Mitchell, The Society of the Muslim Brothers, op. cit., Ref. 34, pp. 27-28.

85. H. al-Banna, Peace in Islam (Cairo: n.p., 1948), available at http://thequranblog.files.wordpress.com/2008/ 06/_4_-peace-in-islam1.pdf (accessed March 2011).

86. al-Banna, ibid.

87. H. al-Banna, Our message in a new phase (Cairo: n.p., appeared in the 1940s), available at http:// thequranblog.files.wordpress.com/2008/06/_5_-our-message-in-a-new-phase.pdf (accessed March 2011).

88. al-Banna, ibid, n. pag.

89. P. Mandaville, Global Political Islam (New York, NY: Routledge, 2007), p. 72.

90. Mandaville, ibid., p. 85. 